\title{
THE EFFECT OF THE LEARNING MEDIA AND THE ABILITY TO THINK CREATIVE OF TO THE ABILITY TO SCIENCE LITERACY STUDENT OF ELEMENTARY SCHOOL
}

\author{
Jajang Bayu Kelana \\ IKIP Siliwangi \\ jajang-bayu@ikipsiliwangi.ac.id
}

\begin{abstract}
This study aims to determine the effect of the learning media and the ability to think creative of to the ability to science literacy student of elementary school. The study was conducted at the grade V SDN Manangga and SDN Tenjonagara Kabupaten Sumedang. Research design using experiment method with treatment by level $2 \times 2$. Data analysis is the two way anava. The results of this study indicate that (1) There were differences in the ability to science literacy of student of study by using ICT media with education aids. (2) There was an interactional of the learning media and the ability to think creative of the ability to science literacy student of elementary school. (3) The ability to science literacy student who have high the ability to high think creative by using ICT media more high compare who have the ability to high think creative by using education aids.(4) The ability to science literacy student who have low the ability to low think creative by using ICT media more low compare who have the ability to low think creative by using education aids.
\end{abstract}

Keywords: learning media, creative thingking, literacy science.

\begin{abstract}
ABSTRAK
Penelitian ini bertujuan untuk mencari pengaruh media pembelajaran dan kemampuan berpikir kreatif terhadap kemampuan literasi sains siswa sekolah dasar. Penelitian ini dilaksanakan di kelas V SDN Manangga dan SDN Tenjonagara Kabupaten Sumedang. Desain penelitian menggunakan metode eksperimen dengan treatment by level $2 \times 2$. Analisis data menggunakan analisis varian 2 jalur (ANOVA). Adapun hasil penelitian ini adalah (1) adanya perbedaan kemampuan literasi sains siswa yang belajar menggunakan media ICT dengan alat peraga. (2) Adanya interaksi antara media pembelajaran dan kemampuan berpikir kreatif terhadap kemampuan literasi sains siswa sekolah dasar. (3) Kemampuan literasi sains siswa yang memiliki kemampuan berpikir kreatif tinggi menggunakan media ICT lebih tinggi dibandingkan siswa yang memiliki kemampuan berpikir kreatif tinggi yang menggunakan alat peraga. (4) kemampuan literasi sains siswa yang memiliki kemampuan berpikir kreatif rendah yang menggunakan media ICT lebih rendah dibandingkan siswa yang memiliki kemampuan berpikir kreatif rendah yang menggunakan alat peraga.
\end{abstract}

Kata Kunci: media pembelajaran, berpikir kreatif, literasi sains.

\section{INTRODUCTION}

At every level of education, students are required to take a number of specific subjects, including natural science (IPA) or Science. According to Bundu (2006: 10) science is a process of activity carried out by scientists in gaining knowledge and attitudes towards these activities. In relation to learning, science should not only be fixed on concepts. But giving direct experience in the development of product mastery, process, and scientific attitude or more broadly mastering scientific literacy (literacy science. 
According toToharudin, et al (2011: 1) says that scientific literacy (literacy science) comes from a combination of two Latin languages, namely literatus meaning marked with letters, literacy or education and scientia means having knowledge. Measurement of scientific literacy carried out by the Program for International Student Assessment (PISA) in 2012, placing Indonesia at the bottom of the list, which is ranked 64th out of 65 participating countries (OECD, 2012: 5). Whereas the 2015 PISA results showed an improved graph. Of the 72 countries that participated, Indonesia ranked 8th from the bottom (Kompas, 2016: 12). There was an increase in the science competency score from 382 in 2012 to 403 in 2015. The value of science obtained by Indonesia was still below the average of 500 of the values set by PISA. That is, it only reaches the international low bencmark. Based on this data, it is clear that the ability of science in Indonesia is still far from expectations. Mastery of science is only limited to material and has not been able to relate it to various more complex or abstract scientific topics.

Samsudin (2016: 77) said that in the field of science is not liked by students. Many students in elementary school experience difficulties in learning. Science is seen as unattractive and most students get very low science learning outcomes. This can be caused by learning ignoring the acquisition of ownership of scientific literacy in students. To develop scientific literacy, a teacher needs to have the ability to design the right learning. The teacher should change the learning pattern from channeling learning into student activities. Learning is not a teacher-dominated process, but requires students to be active and creative in carrying out a number of activities. Eventually students are able to build their knowledge and understanding independently based on their daily experiences. In implementing active, creative and meaningful learning, the effort that can be done is by using learning media. Whether realized or not, the use of learning media is very important in the learning process. But in practice there are not many teachers who use it and are unable to compete with the lecture method. Limitations in the use and weakness of the ability of teachers to create are the main problems in the application of learning media. Learning not only memorizes the material in the book but finds and builds its own knowledge, so that the concepts obtained will be embedded in students' memories. Teachers are not the only source of learning, therefore teachers must be able to plan and make other learning resources. The effort that can be done to make students have a good understanding of scientific literacy is to use ICT media and media props. 
Halidi, Husain and Saehana (2015: 59) say that ICT media is a means that can help teachers to convey messages / information or transfer knowledge knowledge to students. Learning that is packaged in such a way makes the learning process more enjoyable. The use of ICT-based media has implications for students' motivation in learning and can improve their learning outcomes. Meanwhile, according to Engkoswara \& Natawidjaja (1979: 28) teaching aids are aids or complementary tools used by teachers in communicating with students. Props can be in the form of behavior or objects, for example leaves, globe, torso and so on. The objects used are complementary or instrumental to the teacher in teaching and not intended to change the role of the teacher. This is supported by Apriliyanti, et al (2015: 840) which states that the use of teaching aids in learning has proven to make it easier for students to understand the material, because students feel more happy and interested in learning to use teaching aids. Students can be helped in constructing something abstract into reality, including in science learning.

Another factor that influences scientific literacy is the ability to think creatively. Jamaluddin (2010: 204) said that the ability to think creatively is a high-level thinking ability that needs to be developed through elementary science learning. The main objective of learning science is to make students become science literates or scientific literates. For that creative thinking ability is very important to be developed. If students already have the ability to think creatively, they can develop their personality through increasing concentration, intelligence, and confidence. Based on the description above, researchers are interested in conducting research on "The Influence of Learning Media and Creative Thinking Ability Against the Science Literacy Ability of Elementary School Students".

\section{METHOD}

The research design used an experimental method with treatment by level $2 \times 2$. The target population in this study were all fifth grade students in South Sumedang Elementary School as many as 17 public elementary schools. Affordable population of this study are students in grade V of SDN Manangga and SDN Tenjonagara in the 2016/2017 school year as many as 37 students. So a total of 74 students.

\section{RESULTS AND DISCUSSION}

\section{Result}

Based on calculations that have been done manually using two-way ANAVA, analysis is obtained. In the following table: 
Table 1: ANAVA Results of Interaction Between Learning Media and Students 'Creative Thinking Ability Against Students' Literacy Ability.

\begin{tabular}{cccccc}
\hline Variant Source & Db & JK & RJK & $\mathbf{F}_{\text {Count }}$ & $\mathbf{F}_{\text {table }}$ \\
\hline Inter Column & 1 & 42.025 & 42.03 & 7.96 & 4.11 \\
Inter Line & 1 & 27.23 & 27.23 & 5.16 & 4.11 \\
Interaction & 1 & 126.02 & 126.02 & 23.87 & 4.11 \\
In & 36 & 190.10 & 5.28 & & \\
Total Reduced & 39 & 385.375 & & & \\
\hline
\end{tabular}

The test results in the four groups using the Kolmogorov Liliefors test with a significance level $\alpha=0.05$ can be presented as follows:

\section{A. Comparison of Abilities Science Literacy Between ICT Media and Props.}

Variant Analysis Results (ANAVA) in table 1, obtained Fcount $=7.96$ at Ftable (0.05) $=4.11$, then $\mathrm{H}_{0}$ is rejected. So, there are differences in students' scientific literacy abilities using ICT (A1) media with props (A2). The average value of a group of students using ICT (A1) media is XA1 $=20.4$ with a group of students using props (A2) is XA2 $=18.35$. Thus, it can be concluded that students' scientific literacy skills learned through ICT media are higher than students who are taught through teaching aids.

\section{B. Effect of Interaction Between Learning Media and Students 'Creative Thinking Ability Against Students' Literacy Ability.}

Variant Analysis Results (ANAVA) in table 1, obtained Fcount $=23.87$ at Ftable $(0.05)=4.11$, then $\mathrm{H} 0$ is rejected. So, there is a very significant interaction effect between learning media and the ability to think creatively on students' scientific literacy abilities. After knowing the interaction between learning media and students' creative thinking skills, further testing is needed, due to the number of subjects, the further test used is the Tukey test. With the Tukey test it can be stated that there is an influence of the interaction between the provision of learning media and the ability to think creatively.

\section{Differences in Science Literacy Ability Between Students Who Have High Creative Thinking Ability Who Follow Learning Through ICT Media With Teaching Aids.}

Testing uses the Tukey test about differences scientific literacy skills students who have high creative thinking skills who are given media learning with students who have high 
creative thinking skills using teaching aids show that Qcount $=7.71$ and Qtable $=2.042$, then $\mathrm{HO}$ is rejected, meaning that there are significant differences in scientific literacy skills in ICT media with teaching aids in groups of students who have high creative thinking ability or $\mathrm{A} 1 \mathrm{~B} 1>\mathrm{A} 2 \mathrm{~B} 1$ because $\mathrm{XA} 1 \mathrm{~B} 1=23$ and $\mathrm{XA} 2 \mathrm{~B} 1=17.4$.

Thus, it can be concluded that scientific literacy skills of students who have high creative thinking skills using ICT media are higher than students who have high creative thinking abilities who use teaching aids.

\section{Science Literacy Ability of Elementary School Students Who Have Low Creative Thinking Ability}

Given Learning Using ICT Media with Teaching Aids. Testing using the Tukey test about differences in scientific literacy skills students who have high creative thinking skills who are given learning to use media with students who have high creative thinking skills using props show that Qcount $=2.06$ and Qtable $=2.042$, then H0 is rejected, meaning there are significant differences scientific literacy skills in ICT media with teaching aids in groups of students who have high creative thinking ability or A1B2 <A2B2 because XA1B2 = 17.8 and $\mathrm{XA} 2 \mathrm{~B} 1=19.3$.

Thus, it can be concluded that scientific literacy skills of students who have low creative thinking abilities who use ICT media are lower than students who have low creative thinking abilities who use teaching aids.

\section{Discussion}

The results of calculations with the Tukey test obtained the following findings. There are differences in scientific literacy abilities of students who use ICT media and teaching aids that are very significant. Scientific literacy skills of students with ICT media are higher than students who learn to use teaching aids. This is because ICT media is one of the media that is able to display images (audio) and sound (visual) at the same time. The use of ICT media complements the delivery of material provided by the teacher. Teachers can expand student interest beyond the classroom walls. Animals or objects that are large and small can be easily learned and brought into class. Likewise, events that are too dangerous to observe, can be studied safely. The use of ICT media involves various senses that students have. In line with the development of Edgar Dale's cone (Azhar, 2011: 11) which explains that the more the senses are involved, the more likely the information can be understood and remembered. Whereas props are tools used to demonstrate certain places, objects and concepts so that they appear more concrete. Unlike the ICT media, the teaching aids used 
seem to be rigid and focused only on images (visual), so that the use of all student senses cannot be functioned optimally.

The results of the above analysis are strengthened by the results of the calculation of the effectiveness of the use of ICT media and teaching aids as a whole obtained Fcount = 7.96 at Ftable $(0.05)=4.11$, then $\mathrm{H} 0$ is rejected. So, there are differences in students' literacy skills using ICT media with teaching aids. Based on statistical analysis of scientific literacy of elementary school students that are influenced by two independent variables in this study, namely, learning media and the ability to think creatively lead to interaction effects. A teacher must have an understanding of the importance of using learning media. This is to facilitate it in determining which media are considered appropriate in the delivery of learning material in accordance with the learning objectives and conditions of students, including students' creative thinking skills.

This is possible because those who have high creative thinking skills are faster in receiving and capturing subject matter. Conversely, those who have low creative thinking ability will have difficulties in the learning process. Variant Analysis Results (ANAVA) shows Fcount $=23.87$ at Ftable $(0.05)=4.11$, then $\mathrm{H} 0$ is rejected. So, there is a very significant interaction effect between learning media and the ability to think creatively on students' scientific literacy abilities. Thus it can be concluded that in the provision of learning media must be adapted to the ability to think creatively that will help in improving scientific literacy of elementary school students.

In addition, students who have high creative thinking abilities tend to be able to feel and observe problems, make assumptions, assess and test hypotheses, test them and submit conclusions so as to make it easier for them to learn the material presented by the teacher. Students with high creative thinking abilities will be more meaningful if given the treatment of learning with ICT media. This is because the ICT media is able to present actual event documentation in the form of audio and visuals and present them into the classroom, so that it will encourage students to connect the knowledge they get with their daily lives. The products of students who have high creative thinking skills include producing thinking fluently, flexibly, originally and elaboratively.

Unlike the use of props, students with high creative thinking skills will experience difficulties. In the use of teaching aids, students can only see images that are displayed in 2 dimensions without being able to feel the form or event real. So that students who have the ability to think creatively cannot channel their abilities. The results of the above analysis are 
reinforced by the overall calculation results that obtained shows that Qcount $=7.71$ and Qtable $=2.042$, then $\mathrm{H} 0$ is rejected, meaning that there are significant differences in scientific literacy skills in ICT media with teaching aids in groups of students who have high creative thinking ability or A1B1 > A2B1 because XA1B1 = 23 and XA2B1 = 17.4. Thus, it can be concluded that scientific literacy skills of students who have high creative thinking skills who use ICT media are higher than scientific literacy abilities of students who have high creative thinking abilities who use teaching aids.

In learning, students who have low creative thinking skills will have difficulty to feel/ observe problems, make assumptions, assess and test hypotheses, test them and submit conclusions. Therefore, students who have low creative thinking skills prefer to learn in a simple way. So that students feel more able to understand learning material. Students who have low creative thinking skills who learn to use teaching aids can achieve higher success in learning. Learning material delivered is simpler and easier to understand by students who have low creative thinking skills. Meanwhile, students who have low creative thinking abilities who use ICT media will experience difficulties in the learning process. This is because the learning process is only focused on the use of videos displayed by the teacher. In addition, students will feel bored to watch the video delivered so that students do not focus on the learning process. For students who have low creative thinking skills, it will be difficult to describe the number of variables found in complex media. Students with low creative thinking abilities have characteristics less able to optimize existing knowledge and understanding as a whole. All information received will be partially digested and even missed.

The results of the above analysis are reinforced by the results of calculations that show that Qcount $=2.06$ and Qtable $=2.042$, then $\mathrm{H} 0$ is rejected, meaning that there are significant differences in scientific literacy skills in ICT media with teaching aids in groups of students who have high creative thinking skills or A1B2 $\angle \mathrm{A} 2 \mathrm{~B} 2$ because XA1B2 $=17.8$ and $\mathrm{XA} 2 \mathrm{~B} 1=19.3$. Thus, it can be concluded that scientific literacy of students who are given treatment with ICT media that have low creative thinking ability is lower than those who use teaching aids that have low creative thinking abilities.

\section{CONCLUSION}

First, scientific literacy skills of elementary school students who study with ICT media are higher than those who learn to use teaching aids. Second, there is an effect of 
interaction between the use of learning media and the ability to think creatively on scientific literacy skills of elementary school students. Third, elementary school students' scientific literacy abilities between students who study with ICT media who have high creative thinking skills are higher than students who learn with teaching aids that have high creative thinking skills. Fourth, elementary school students' literacy skills between students who study with ICT media who have low creative thinking skills are lower than students who learn with teaching aids that have low creative thinking skills.

\section{REFERENCES}

Apriliyanti, Dwi Dharis, Haryani, Sri Dan Widiyatmoko, Arif. (2015). "Pengembangan Alat Peraga IPA Terpadu Pada Tema Pemisahan Campuran Untuk Meningkatkan Keterampilan Proses Sains," Unnes Science Education Journal 4 (2), http://journal.unnes.ac.id/sju/index.php/usej (diakses 30 September 2018).

Aryad. Azhar, (2011). “Media Pembelajaran”. Jakarta: Rajawali Press.

Bundu, Patta. (2006). "Penilaian Keterampilan Proses dan Sikap Ilmiah dalam Pembelajaran Sains Sekolah Dasar”. Jakarta : Depdikbud.

Engkoswara \& Natawidjaja, Rochman. (1979). “Alat Peraga dan Komunikasi Pendidikan untuk SPG” Jakarta: Deksikbud..

Halidi, Mahmud Hasan., Husain, N.Sarjan dan Saehana, Sahrul. (2015). "Pengaruh Media Pembelajaran Berbasis TIK terhadap Motivasi dan Hasil Belajar IPA Siswa Kelas V SDN Model Terpadu Madani Palu”, e-Jurnal Mitra Sains, Volume 3 Nomor 1, Januari $2015 \quad \mathrm{hlm} \quad 53-60, \quad$ jurnal.untad.ac.id/jurnal/index.php/MitraSains/ article/download/4153/3090 (diakses 30 September 2018).

Jamaluddin, (2010).“Kemampuan Berpikir Kreatif Siswa SD dalam Pembelajaran IPA”, Jurnal Ilmu Pendidikan, Jilid 17, Nomor 3, Oktober 2010, hlm. 202-209.

Kompas, (2016).“Literasi sains Membaik”. Kompas

OECD, (2012). "PISA 2012 Results in Focus What 15-year-olds know and what they can do with what they know". OECD.

Samsudin, 2014. "Suvervisi Akademik Pembelajaran IPA Melalui ICT Based Lesson Study Untuk Membangun Learning Community Guru SD”, Mimbar Sekolah Dasar; Volume 1, Nomor 1, April 2014 PGSD UPI Kampus Sumedang, hlm. 77.

Toharudin, Uus., Hendrawati, Sri dan Rustaman, Andrian. (2011). “Membangun literasi Sains Peserta Didik". Bandung: Humaniora 